Note

\title{
Value Creators: an innovative learning environment to shape the future together and find glocal soulutions to the challenges ahead
}

\author{
María García Alvarez ${ }^{1 *}$, Liesbeth Rijsdijk²
}

1. Lecturer and Coordinator Value Creators Programme, Windesheim Honours College, the Netherlands; mf.garcia-alvarez@windesheim.nl

2. Director External Relations and International Affairs Windesheim Honours College, the Netherlands; e.rijsdijk@windesheim.nl

*_Correspondence: $\underline{\text { mf.garcia-alvarez@windesheim.nl }}$

Received: 11 September 2017; Accepted: 16 October 2017; Published: 18 October 2017

Keywords: bounded freedom, wicked problems, network learning, education on demand

\section{Introduction}

The world is becoming more complex and educational institutions need to adjust to the demands of this new phase of our network society. In this age of globalization, rapid and disruptive changes and technological developments, society and organisations are increasingly confronted with developments and challenges which are more and more "wicked" in nature. Global warming, different human rights issues, the world economic crisis, an increasing gap between rich and poor, food security and depletion of resources to name a few. These challenges are difficult, if not impossible, to solve, and for each solution, due to interdependencies, other questions and challenges arise (Rijsdijk \& de Bot, 2017).

These wicked challenges require other ways of thinking and addressing compared to challenges which can be defined in terms of cause and effect (linear) and for which there are definite solutions available. To prepare students for their future role as project and change managers addressing wicked challenges, Windesheim Honours College (WHC) in the Netherlands, developed an innovative educational concept which is called The Value Creators. WHC offers an honours bachelor programme (BBA) in Global Project and Change Management. The programme is English-taught and selects international students based on motivation, above-average ability and social involvement. In the Value Creators semester, third and fourth year students work on a wicked challenge. During this semester, students develop essential 21st century skills like social responsibility, collaboration and leadership, creativity and innovation, critical thinking and problem solving in four areas: Civil Society, Global Health, Social Entrepreneurship and Urban Dynamics. We developed our own methodology for value creation: The E-model. It is based on Design thinking, connectivism (Siemens, 2005) and Theory U (Scharmer \& Kaufer, 2013). It describes four essential phases 
to lead interdisciplinary teams through value creation when dealing with wicked challenges and complexity.

The Value Creators programme offers students and other stakeholders an environment to shape the future together and address wicked challenges from a local and global perspective.

\section{Methods}

In close consultation with our students and professional networks, we have been able to create a solid educational concept based in connectivism theory (Siemens, 2005), Theory U (Scharmer \& Senge, 2009), Five Minds for the Future (Gardner, 2008) and communities of practice (Wenger, 1998). We wanted to create an environment which facilitates the transition from knowledge as a goal to knowledge as a tool. Bounded freedom is a fundamental part of the DNA of the Windesheim Honours College. In the Value Creators programme we have extended bounded freedom by taking away the class schedules and operating with education on demand. Through different workshops which we provide and which students can create on demand, they build up their own toolbox to operate outside, discovering and engaging with professional networks. We offer four fields of expertise to experience Value Creators: Social Entrepreneurship, Civil Society, Global Health and Urban Dynamics. We have chosen those topics in alignment with EU agendas as well as local and regional agendas. We invite our students to explore the knowledge related to those topics which are embedded in different networks outside the campus. For that, we also share space with policy makers, entrepreneurs and other organizations in a collaborative working hub (called Brainz) in the city of Zwolle. The Value Creators journey departs from a complex question. Students can team up with other fellow students from different disciplines. Together they start identifying networks which can play an important role in activating change and creating value.

In order to help students navigate through the process of addressing complex issues, we developed the E-Model. Inspired by traditional forms of design thinking and incorporating elements of different theories mentioned before, this model is a simple method to help students and other stakeholders to focus, to identify the most important stakeholders and ingredients to take action and create societal change and value. The E-model consists of four steps:

- Step 1. Explore: We invite students (and other users of the model) to explore the wicked challenge they are addressing. Exploring the context, possible causes and possible solutions helps gain expertise in the topic. This is the time for brainstorming and shaping good questions and discussing together the Big Dream.

- Step 2. Engage: It is time to map the networks and identify stakeholders who can be key players in solving the complexity that is being addressed. Who are they and why are they relevant in this process? Are they part of the problem or of the solution? What is their specific role or power in moving things forward?

- Step 3. Elaborate: It is time to shape the ideas and be more specific on the role of each network and stakeholder in addressing the wicked challenge and defining the activities that each stakeholder should undertake. It is about going from Dream to Action. 
- Step 4. Evaluate: This is the final phase of the model. The participants define which value will be created for whom and how it will be evaluated.

To make the Value Creators journey as valuable as possible for our students, we introduced a self-assessment practice. Students are in control of $25 \%$ of their grade. In order to do this, we plan three individual meetings with them. In the first meeting, we invite them to reflect using the framework of the 5 Minds for the Future (Gardner, 2008). Based on this reflection, they have to create their own learning objectives linked to the 5 Minds Model and our own Value Creators' learning objectives. Then they need to think about two goals they want to achieve during their Value Creators journey at personal, professional and community level. In the second meeting we discuss issues they are experiencing, extra tools they may need to achieve their goals, etcetera. In the last meeting, students need to assess their own learning journey and present the evidence to sustain the grade they are claiming in front of a professional jury, consisting of lecturers, professors and work field representatives.

\section{Results}

Our Value Creators programme was piloted in 2016-2017 with great expectations from students and lectures. During the whole year, we have worked closely together with our students exchanging information on how to improve the concept. Students experienced the Value Creators as one of the most insightful learning moments of their whole life as students. This of course makes us feel very proud. However, we cannot ignore the fact that extreme bounded freedom has been difficult for some students who feel more comfortable inside structures that facilitate their time management. It is important that students get proper training in previous years on how to take ownership of their own learning journey. We have developed four high quality SPOOCs (Small Private Owned Online Courses) to contribute to the discipline mind of students and allowing them to speak the language of other professionals in the field of expertise they have chosen. Next to the mandatory workshops, we mainly focus on training them in complexity, networks and how to self-assess themselves. We also allow a 4 EC free choice, which can consist of following a MOOC of their interest or attending conferences and seminars. Providing some structure does help to lead the students through this quite open and organic process of the Value Creators semester.

The Value Creators have been a learning process for lecturers as well. They need to take a step back from their role as lecturers and need to become coaches who guide the learning process and reflection of the students. The next step for our concept is to develop an online learning community which allows us to take the collaboration process of creating value and learning into a virtual setting with no time or space constrains. This will facilitate the process of connecting to international networks. It is also our aim to extend the concept to other universities. This way, we could have cells of Value Creators operating in different countries and working on complex issues from different disciplines and perspectives. We invite other educational institutions to contact us to join the exciting journey of creating societal value together.

\section{Discussion}

New concepts of education are necessary in order to address the demands from the work field regarding young professionals who are focused on quality and value. However, they do require commitment and investment of time and money from the educational institutions in 
order to develop effective methods. One size does not fit all. This also applies for innovative concepts. In the case of the Value Creators, the concept matches the progression of bounded freedom, experiential learning and self-reflection embedded in previous years of our curriculum. It is therefore a building block, also preparing them for their final bachelor year.

\section{Conclusions}

Value Creators have contributed to expand bounded freedom in an already flexible curriculum focused on addressing the individuality of each student, and particularly addressing complexity and networks. It is an organic concept, meaning we expect it to grow and develop depending on the students, networks and topics that we will be working on within the Value Creators setting every year. It is a concept that not only allows those dynamics but aims to create environments that are not static. This may take an extra effort when the limits are not clearly drawn, but we do not have a recipe for value, just the framework to facilitate creating it and eventually, make it happen.

\section{References}

More information can be found at: $h t t p s: / / w w w . w i n d e s h e i m . c o m / s t u d y-$ programmes/bachelor-degrees/global-project-and-change-management/education-curriculum/value-creators/

Gardner, H. (2008). The five minds for the future. Schools, 5(1/2), 17-24.

Rijsdijk, E. \& Bot, M. de (2017, September). Wicked questions and developing Leadership competences in a network society. Preparing young professionals for the future. Paper presented at the IPMA World Congress, Astana, Kazakhstan.

Scharmer, C. O., \& Kaufer, K. (2013). Leading from the Emerging Future. From Ego-System to Eco-System Economies. Applying theory $U$ to transforming business, society, and self. Oakland, CA (USA): Berret-Koehler.

Scharmer, C. O., \& Senge, P. M. (2009). Theory U: Leading from the future as it emerges. San Francisco, CA (USA): Berett-Koehler.

Siemens, G. (2005). Connectivism: Learning as network-creation. ASTD Learning News, 10(1), $1-28$.

Wenger, E. (1998). Communities of practice: Learning as a social system. Systems thinker, 9(5), 2-3. 